\section{OPEN ACCESS}

Edited by:

Leonardo Alexandre Peyré-Tartaruga,

Federal University of Rio

Grande do Sul, Brazi

Reviewed by:

Andreas Fahlman,

Fundación Oceanogràfic de la

Comunitat Valenciana, Spain

*Correspondence:

Michael S. Tift

tiftm@uncw.edu

Specialty section:

This article was submitted to Integrative Physiology, a section of the journal Frontiers in Physiology

Received: 17 March 2019 Accepted: 13 May 2019

Published: 04 June 2019

Citation:

Tift MS and Ponganis PJ (2019) Time

Domains of Hypoxia

Adaptation-Elephant Seals Stand

Out Among Divers.

Front. Physiol. 10:677.

doi: 10.3389/fphys.2019.00677

\title{
Time Domains of Hypoxia Adaptation-Elephant Seals Stand Out Among Divers
}

\begin{abstract}
Michael S. Tift ${ }^{1 *}$ and Paul J. Ponganis ${ }^{2}$
${ }^{1}$ Department of Biology and Marine Biology, University of North Carolina Wilmington, Wilmington, NC, United States, ${ }^{2}$ Center for Marine Biotechnology and Biomedicine, Scripps Institution of Oceanography, University of California, San Diego, La Jolla, CA, United States
\end{abstract}

Keywords: blood oxygen transport, carbon monoxide, dive, hemoglobin, hypoxia tolerance, lung, myoglobin, ischemia reperfusion injury

\section{INTRODUCTION}

In this Opinion, adaptations to hypoxia are examined during the short time domains of breath holds from three accomplished diving animals: northern elephant seals (Mirounga angustirostris), California sea lions (Zalophus californianus), and emperor penguins (Aptenodytes forsteri). Review of dive behavior, oxygen $\left(\mathrm{O}_{2}\right)$ storage, and arterial blood $\mathrm{O}_{2}$ profiles during dives reveals that the elephant seal undergoes the most frequent and extreme hypoxemia. Exceptional breath hold durations, routine hypoxemia, established research protocols, and accessibility to the animals make the elephant seal stand out for physiological investigation and evaluation of biochemical/molecular adaptations in hypoxemic tolerance, protection against re-perfusion injury, and $\mathrm{O}_{2}$ transport during dives.

The northern elephant seal and southern elephant seal (M. leonina) are the premier pinniped divers (Le Boeuf et al., 1988; Hindell et al., 1991, 1992; Hassrick et al., 2010; Robinson et al., 2012). During several month-long trips to sea, these animals spend $80-90 \%$ of their time underwater, perform routine dives of $20-30 \mathrm{~min}$ duration to average depths $>400 \mathrm{~m}$, have short inter-dive surface intervals that average two min, and typically gain about one $\mathrm{kg} \mathrm{d}^{-1}$ in body mass.

In contrast to elephant seals, California sea lions only spend about $30 \%$ of their time at sea diving (Feldkamp et al., 1989). Most dives are $<100 \mathrm{~m}$ in depth and between 1 and 4 min in duration (McDonald and Ponganis, 2013; Tift et al., 2017). However, dependent on geographic location, climate variability, and prey distribution, these sea lions can regularly perform 10-min dives to $400-500 \mathrm{~m}$, with the current longest reported dive of $16 \mathrm{~min}$ (Melin et al., 2008; McHuron et al., 2016, 2018).

Emperor penguins are the premier avian divers; they exploit the entire water column to depths $>500 \mathrm{~m}$. Shallower dives are up to $5-6 \mathrm{~min}$ in duration while deep dives are about 10 min (Kooyman and Kooyman, 1995; Kirkwood and Robertson, 1997; Sato et al., 2011). The longest dive documented by a continuous dive profile in an emperor penguin is $27.6 \mathrm{~min}$. During foraging trips to sea, emperor penguins spent about $31 \%$ of their time resting on the sea ice (Watanabe et al., 2012). 


\section{$\mathrm{O}_{2}$ STORES: MAGNITUDE, DISTRIBUTION AND UTILIZATION}

The magnitude and distribution of respiratory, blood, and muscle $\mathrm{O}_{2}$ stores are dependent on diving lung volume, blood volume, hemoglobin $(\mathrm{Hb})$ concentration, muscle mass, myoglobin $(\mathrm{Mb})$ concentration, and the quantity of extractable $\mathrm{O}_{2}$ from each store (i.e., reduction in $\mathrm{Hb}$ saturation during a dive). As recently reviewed (Ponganis, 2015), total body $\mathrm{O}_{2}$ stores have been estimated at 94,55 , and $68 \mathrm{ml} \mathrm{O}_{2} \mathrm{~kg}^{-1}$ body mass for elephant seals, California sea lions, and emperor penguins, respectively. The distribution of these stores varies considerably with 68,39 , and $31 \%$ in the blood, 28,48 , and $36 \%$ in muscle, and 4,13 , and $33 \%$ in the respiratory system of elephant seals, California sea lions, and emperor penguins, respectively.

The cardiovascular dive response (the decrease in heart rate (bradycardia) and increase in peripheral vascular resistance associated with a breath hold) and pulmonary gas exchange play a critical role in blood $\mathrm{O}_{2}$ utilization and arterial partial pressure of $\mathrm{O}_{2}\left(\mathrm{P}_{\mathrm{O} 2}\right)$ profiles during dives. Heart rate is a primary determinant of pulmonary blood flow and, consequently, extraction of $\mathrm{O}_{2}$ from the lung. Vasoconstriction and redistribution of peripheral blood flow which accompany the bradycardia result in a decreased blood $\mathrm{O}_{2}$ extraction by tissue, thus slowing the depletion rate of the blood $\mathrm{O}_{2}$ store (Irving et al., 1941; Valtin, 1973; Lutz et al., 1975; Kvietys and Granger, 1982). Elephant seals, California sea lions, and emperor penguins all display variability in the degree of diving bradycardia which can be dependent on the depth and nature of a given dive (Andrews et al., 1997; Meir et al., 2008; McDonald and Ponganis, 2014; Wright et al., 2014).

Cessation of gas exchange at depth due to alveolar collapse (100\% pulmonary shunt) also affects arterial oxygenation patterns during dives in marine mammals (Kooyman et al., 1970, 1973a; Kooyman and Sinnett, 1979, 1982; Falke et al., 1985; Fahlman et al., 2009, 2017; McDonald and Ponganis, 2012). In penguins, it is unclear if gas exchange ceases at depth (Kooyman et al., 1973b).

\section{ARTERIAL PO2 AND HEMOGLOBIN SATURATION PROFILES DURING DIVES}

Arterial $\mathrm{P}_{\mathrm{O} 2}$ profiles and calculated $\mathrm{Hb}$ saturation profiles have been obtained during dives of these three species (Figure 1) with use of intravascular $\mathrm{P}_{\mathrm{O} 2}$ electrodes, backpack bio-loggers, and $\mathrm{O}_{2}-\mathrm{Hb}$ dissociation curves on free-diving animals (Meir and Ponganis, 2009; Meir et al., 2009; McDonald and Ponganis, 2012, 2013; Tift et al., 2017, 2018). Among these three elite divers, it is the elephant seal that experiences routine and extreme arterial hypoxemia with arterial $\mathrm{Hb}$ saturations below $80 \%$ for $\sim 80 \%$ of dive durations (Figure 1). Although hypoxemia likely occurs in the other two species, it is notable that their arterial $\mathrm{Hb}$ saturations can remain above $90 \%$ for almost $90 \%$ of the dive duration (Figure 1). In sea lions and penguins, the maintenance of high arterial $\mathrm{Hb}$ saturations throughout much of the dive are attributable, at least in part, to (a) diving on inspiration not expiration (Sato et al., 2002; Fahlman et al., 2008; McDonald and Ponganis, 2012; Tift et al., 2017), (b) larger respiratory fraction of total $\mathrm{O}_{2}$ stores, and (c) maintenance of gas exchange at deeper depths.

The elephant seal also experiences significant arterial $\mathrm{Hb}$ desaturation during its spontaneous, frequent sleep apneas on land (Stockard et al., 2007). All these studies reveal that elephant seals encounter hypoxemia far more often in their life cycle than either California sea lions or emperor penguins. Based upon the Krogh Principle (Krebs, 1975), elephant seals are ideal models for investigation of the physiological and biochemical mechanisms of hypoxemic tolerance in divers.

\section{CEREBRAL HYPOXEMIC PROTECTION}

In general, there are three factors in seals that contribute to enhanced brain $\mathrm{O}_{2}$ delivery during breath holds: (a) high $\mathrm{Hb}$ concentrations, (b) hypercarbia (leading to decreased $\mathrm{Hb}$ $\mathrm{O}_{2}$ affinity and an increase in cerebral blood flow, and (c) increased brain capillary density (Kerem and Elsner, 1973). In addition, selective brain cooling and potential cerebro-protection can occur via arterio-venous shunting in the foreflippers with brain temperature declines of $3-4^{\circ} \mathrm{C}$ during 15 -min forced submersions (Blix et al., 2010). Some notable biochemical and molecular adaptations in the seal brain include: (a) a 3-fold elevation in brain glycogen, (b) normal lactate dehydrogenase (LDH) activity with $>70 \% \mathrm{LDH} 1$ and 2 isoenzymes (lactate oxidation), primarily located in glial cells, (c) increased gene expression of S100B (a stress protein with calcium binding activity), clustrin (an extracellular chaperone molecule), and most glycolytic enzymes, but decreased expression of pyruvate dehydrogenase, and (d) normal neuroglobin and cytochrome oxidase gene expression, but, in contrast to terrestrial mammals, located in glial cells (Mitz et al., 2009; Schneuer et al., 2012; Czech-Damal et al., 2014; Fabrizius et al., 2016; Hoff et al., 2016, 2017). The ability to study elephant seals during their voluntary sleep apnea events, which can include routine tenmin breath holds even inside an NMR scanner (Ponganis et al., 2008), make them ideal model organisms to investigate metabolic rate, glucose consumption, and blood flow in brain and muscle with advanced scanning techniques, such as functional magnetic resonance imaging, positron emission tomography, and nearinfrared diffuse correlation spectroscopy (Ridgway et al., 2006; Smith et al., 2013; Shang et al., 2017).

\section{AVOIDANCE OF RE-PERFUSION INJURY}

Re-perfusion injury occurs when $\mathrm{O}_{2}$-rich blood returns to previously ischemic and hypoxic tissues, and is often associated with reactive oxygen species (ROS) generation, intracellular calcium accumulation, and inflammation (Powers and Jackson, 2008). In the seal heart, although a 10 -fold elevation in glycogen content may provide a large glycolytic energy store and prevent intracellular calcium accumulation during ischemia/hypoxemia, an impressive 25-fold elevation in glutathione content should 


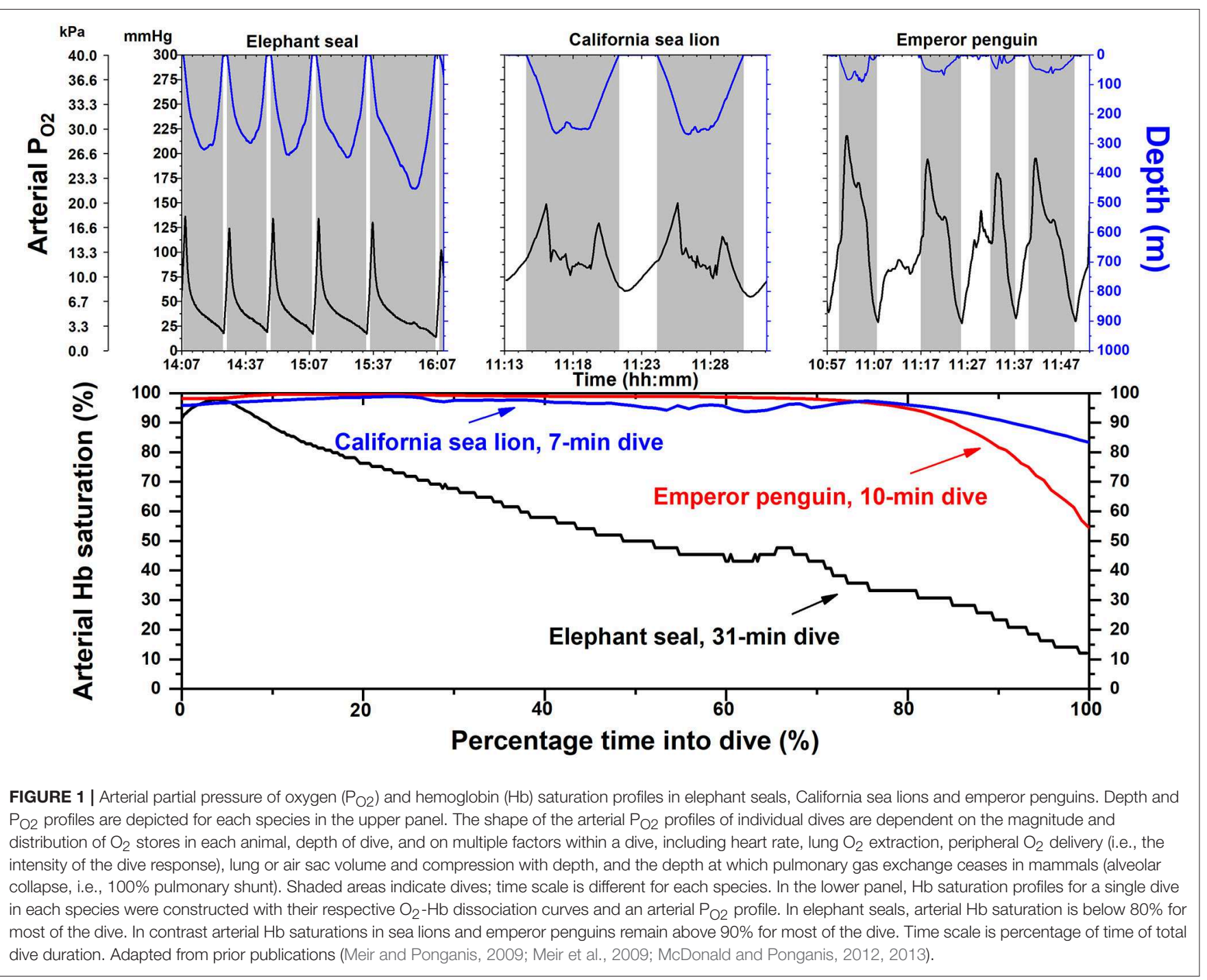

also enhance the potential for scavenging of ROS during reperfusion (Henden et al., 2004; Vázquez-Medina et al., 2007). Significant elevations in glutathione content were also found in seal kidney, lung, and muscle. In all tissues, enzymes associated with the recycling of glutathione were elevated. In addition to enhanced scavenging of ROS, it has also been found that the whole blood inflammatory response of seals on exposure to a potent endotoxin (lipopolysaccharide-LPS) is significantly blunted (Bagchi et al., 2018). Interleukin-6 cytokine production in blood was 50-500 times lower in elephant seals and Weddell seals (Leptonychotes weddellii) than in humans. Lastly, endogenous carbon monoxide (CO) levels are high in these two species with carboxyhemoglobin levels as high as $10 \%$ in elephant seals (Pugh, 1959; Tift et al., 2014). Such high $\mathrm{CO}$ levels raise the possibility that $\mathrm{CO}$ may play a role in the prevention of inflammatory responses during re-perfusion. Exposure to moderate levels of exogenous $\mathrm{CO}$ has shown to exhibit potent anti-inflammatory effects (Motterlini and Otterbein, 2010). Again, elephant seals represent ideal models for further investigation in re-perfusion injury avoidance and the physiological role of endogenous $\mathrm{CO}$, with established protocols in place to examine tissue stress responses and collect serial blood samples during voluntary breath-holds (Stockard et al., 2007; Vazquez-Medina et al., 2011a,b; Tift et al., 2013, 2014).

\section{$\mathrm{O}_{2}$ TRANSPORT: HEMOBLOBIN $\mathrm{O}_{2}$ AFFINITY}

Although the presence of carboxyhemoglobin should decrease the start-of-dive blood $\mathrm{O}_{2}$ store of the elephant seal, the increased $\mathrm{Hb}-\mathrm{O}_{2}$ affinity induced by the presence of $\mathrm{CO}$ may be beneficial for $\mathrm{O}_{2}$ delivery during dives. Increased $\mathrm{Hb}-\mathrm{O}_{2}$ affinity is advantageous during severe hypoxia because it promotes $\mathrm{O}_{2}$ uptake from the lung and increases the $\mathrm{O}_{2}$ content of blood at a given arterial $\mathrm{P}_{\mathrm{O} 2}$. The $\mathrm{Hb}-\mathrm{O}_{2}$ affinity is increased in penguins and in a variety of mammals and birds adapted to live in hypoxic environments or at high altitude (Milsom et al., 1973; Black 
and Tenney, 1980; Weber, 2007; Meir and Ponganis, 2009; Storz et al., 2010; Storz, 2016; Weber et al., 2017). In many pinnipeds, including elephant seals, the $\mathrm{Hb}-\mathrm{O}_{2}$ affinity is not known to be high; their $\mathrm{P}_{50}$ values $\left(\mathrm{P}_{\mathrm{O} 2}\right.$ at $50 \% \mathrm{Hb}$ saturation: low values $=$ high $\mathrm{Hb}-\mathrm{O}_{2}$ affinity) were $25-30 \mathrm{~mm} \mathrm{Hg}(3.3-4.0 \mathrm{kPa})$ which resemble values seen in hypoxia intolerant species (Lenfant et al., 1969, 1970; Qvist et al., 1981; Meir et al., 2009; McDonald and Ponganis, 2013). However, in several species of cetaceans, high $\mathrm{Hb}-\mathrm{O}_{2}$ affinities have been reported, with $\mathrm{P}_{50}$ values ranging from 19 to $25 \mathrm{~mm} \mathrm{Hg}(2.5-3.3 \mathrm{kPa}$ ) (Horvath et al., 1968; Dhindsa et al., 1974; Vedvick and Itano, 1976). In the manatee, the $\mathrm{P}_{50}$ was near $16 \mathrm{~mm} \mathrm{Hg}(2.1 \mathrm{kPa}$ ) (White et al., 1976; Farmer et al., 1979). The lack of a relative increase in $\mathrm{Hb}-\mathrm{O}_{2}$ affinity of pinnipeds in contrast to that in other divers (penguins, cetaceans, manatees) warrants further investigation of carboxyhemoglobin levels, blood $\mathrm{O}_{2}$ contents, $\mathrm{O}_{2}-\mathrm{Hb}$ binding characteristics in the presence vs. absence of $\mathrm{CO}$, and blood-to-tissue $\mathrm{O}_{2}$ transfer. The elephant seal is ideal with its high $\mathrm{CO}$ values, long dives and sleep apneas, its established research/blood sampling protocols (translocation studies at sea and sleep apnea studies on land), and its accessibility for research (Stockard et al., 2007; Ponganis et al., 2008; Meir et al., 2009; Tift et al., 2013).

\section{CONCLUSIONS}

Elephant seals, sea lions, and emperor penguins are all highly adapted to perform remarkable dives. However, it is the elephant

\section{REFERENCES}

Andrews, R. D., Jones, D. R., Williams, J. D., Thorson, P. H., Oliver, G. W., Costa, D. P., et al. (1997). Heart rates of northern elephant seals diving at sea and resting on the beach. J. Exp. Biol. 200, 2083-2095.

Bagchi, A., Batten, A. J., Levin, M., Allen, K. N., Fitzgerald, M. L., Hückstädt, L. A., et al. (2018). Intrinsic anti-inflammatory properties in the serum of two species of deep-diving seal. J. Exp. Biol. 221:jeb178491. doi: 10.1242/jeb.178491

Black, C. P., and Tenney, S. M. (1980). Oxygen transport during progressive hypoxia in high-altitude and sea-level waterfowl. Respir. Physiol. 39, 217-239. doi: 10.1016/0034-5687(80)90046-8

Blix, A. S., Walloe, L., Messelt, E. B., and Folkow, L. P. (2010). Selective brain cooling and its vascular basis in diving seals. J. Exp. Biol. 213, 2610-2616. doi: $10.1242 /$ jeb.040345

Czech-Damal, N. U., Geiseler, S. J., Hoff, M. L., Schliep, R., Ramirez, J. M., Folkow, L. P., et al. (2014). The role of glycogen, glucose and lactate in neuronal activity during hypoxia in the hooded seal (Cystophora cristata) brain. Neuroscience 275, 374-383. doi: 10.1016/j.neuroscience.2014.06.024

Dhindsa, D. S., Metcalfe, J., Hoversland, A. S., and Hartman, R. A. (1974). Comparative studies of the respiratory functions of mammalian blood X. Killer whale (Orcinus orca linnaeus) and beluga whale (Delphinapterus leucas). Respir. Physiol. 20, 93-103. doi: 10.1016/0034-5687(74)90099-1

Fabrizius, A., Hoff, M. L. M., Engler, G., Folkow, L. P., and Burmester, T. (2016). When the brain goes diving: transcriptome analysis reveals a reduced aerobic energy metabolism and increased stress proteins in the seal brain. BMC Genomics 17, 1-11. doi: 10.1186/s12864-016-2892-y

Fahlman, A., Hastie, G. D., Rosen, D. A. S., Naito, Y., and Trites, A. W. (2008). Buoyancy does not affect diving metabolism during shallow dives in Steller sea lions Eumetopias jubatus. Aquat. Biol. 3, 147-154. doi: 10.3354/ab00074

Fahlman, A., Hooker, S. K., Olszowka, A., Bostrom, B. L., and Jones, D. R. (2009). Estimating the effect of lung collapse and pulmonary shunt on gas exchange seal that undergoes the most frequent and extreme arterial hypoxemia due to its continuous dive behavior and sleep apneas on land. These factors, in addition to (a) extensive knowledge of biochemical and molecular adaptations to hypoxia in seals, (b) established sleep apnea and dive research protocols, and (c) its accessibility on the California coast make the elephant seal stand out for investigation of time domains of hypoxia adaptation in diving animals.

\section{DATA AVAILABILITY}

The datasets for this manuscript are not publicly available because they have not been uploaded to a public database. Requests to access the datasets should be directed to pponganis@ucsd.edu.

\section{AUTHOR CONTRIBUTIONS}

MT and PP wrote sections of the manuscript, contributed to manuscript revision, read, and approved the submitted version.

\section{ACKNOWLEDGMENTS}

The authors would like to thank the UCSD Center for Physiological Genomics of Low Oxygen (CPGLO) for the invitation to submit this manuscript. PP was supported by NSF1656077-1. during breath-hold diving: the Scholander and Kooyman legacy. Respir. Physiol. Neurobiol. 165, 28-39. doi: 10.1016/j.resp.2008.09.013

Fahlman, A., Moore, M. J., and Garcia-Parraga, D. (2017). Respiratory function and mechanics in pinnipeds and cetaceans. J. Exp. Biol. 220, 1761-1773. doi: $10.1242 / \mathrm{jeb} .126870$

Falke, K. J., Hill, R. D., Qvist, J., Schneider, R. C., Guppy, M., Liggins, G. C., et al. (1985). Seal lungs collapse during free diving: evidence from arterial nitrogen tensions. Science 229, 556-558. doi: 10.1126/science. 4023700

Farmer, M., Weber, R. E., Bonaventura, J., Best, R. C., and Domming, D. (1979). Functional properties of helmoglobin and whole blood in an aquatic mammal, the Amazonian manatee (Trichechus inunguis). Comp. Biochem. Physiol. A 62, 231-238. doi: 10.1016/0300-9629(79)90761-8

Feldkamp, S. D., DeLong, R. L., and Antonelis, G. A. (1989). Diving patterns of California sea lions, Zalophus californianus. Can. J. Zool. 67, 872-883. doi: 10.1139/z89-129

Hassrick, J. L., Crocker, D. E., Teutschel, N. M., McDonald, B. I., Robinson, P. W., Simmons, S. E., et al. (2010). Condition and mass impact oxygen stores and dive duration in adult female northern elephant seals. J. Exp. Biol. 213, 585-592. doi: $10.1242 /$ jeb. 037168

Henden, T., Aasum, E., Folkow, L., Mjøs, O. D., Lathrop, D. A., and Larsen, T. S. (2004). Endogenous glycogen prevents $\mathrm{Ca}^{2+}$ overload and hypercontracture in harp seal myocardial cells during simulated ischemia. J. Mol. Cell. Cardiol. 37, 43-50. doi: 10.1016/j.yjmcc.2004.03.013

Hindell, M. A., Slip, D. J., and Burton, H. R. (1991). The diving behaviour of adult male and female southern elephant seals, Mirounga leonina (Pinnipedia: Phocidae). Aust. J. Zool. 39, 595-619. doi: 10.1071/ZO9910595

Hindell, M. A., Slip, D. J., Burton, H. R., and Bryden, M. M. (1992). Physiological implications of continuous, prolonged, and deep dives of southern elephant seals. Can. J. Zool. 70, 370-379. doi: 10.1139/z92-055

Hoff, M. L. M., Fabrizius, A., Czech-Damal, N. U., Folkow, L. P., and Burmester, T. (2017). Transcriptome analysis identifies key metabolic changes in the hooded 
seal (Cystophora cristata) brain in response to hypoxia and reoxygenation. PLoS ONE 12:e0169366doi: 10.1371/journal.pone.0169366

Hoff, M. L. M., Fabrizius, A., Folkow, L. P., and Burmester, T. (2016). An atypical distribution of lactate dehydrogenase isoenzymes in the hooded seal (Cystophora cristata) brain may reflect a biochemical adaptation to diving. J. Comp. Physiol. B 186, 373-386. doi: 10.1007/s00360-015-0956-y

Horvath, S. M., Chiodi, H., Ridgway, S. H., and Azar Jr., S. (1968). Respiratory and electrophoretic characteristics of hemoglobin of porpoises and sea lion. Comp. Biochem. Physiol. 24, 1027-1033. doi: 10.1016/0010-406X(68)90815-3

Irving, L., Scholander, P. F., and Grinnell, S. W. (1941). Significance of the heart rate to the diving ability of seals. J. Cell. Comp. Physiol. 18, 283-297. doi: $10.1002 /$ jcp. 1030180302

Kerem, D., and Elsner, R. (1973). Cerebral tolerance to asphyxial hypoxia in the harbor seal. Respir. Physiol. 19, 188-200. doi: 10.1016/0034-5687(73)90077-7

Kirkwood, R., and Robertson, G. (1997). The foraging ecology of female emperor penguins in winter. Ecol. Monogr. 67, 155-176. doi: 10.1890/00129615(1997)067[0155:TFEOFE]2.0.CO;2

Kooyman, G. L., Hammond, D. D., and Schroeder, J. P. (1970). Bronchograms and tracheograms of seals under pressure. Science 169, 82-84. doi: 10.1126/science.169.3940.82

Kooyman, G. L., and Kooyman, T. G. (1995). Diving behavior of emperor penguins nurturing chicks at Coulman Island, Antarctica. Condor 97, 536-549. doi: $10.2307 / 1369039$

Kooyman, G. L., Schroeder, J. P., Denison, D. M., Hammond, D. D., Wright, J. J., and Bergman, W. D. (1973a). Blood $\mathrm{N}_{2}$ tensions of seals during simulated deep dives. Am. J. Physiol. 223, 1016-1020. doi: 10.1152/ajplegacy.1972.223.5.1016

Kooyman, G. L., Schroeder, J. P., Greene, D. G., and Smith, V. A. (1973b). Gas exchange in penguins during simulated dives to 30 and $68 \mathrm{~m}$. Am. J. Physiol. 225, 1467-1471. doi: 10.1152/ajplegacy.1973.225.6.1467

Kooyman, G. L., and Sinnett, E. E. (1979). Mechanical properties of the harbor porpoise lung. Respir. Physiol. 36, 287-300. doi: 10.1016/0034-5687(79)90042-2

Kooyman, G. L., and Sinnett, E. E. (1982). Pulmonary shunts in harbor seals and sea lions during simulated dives to depth. Physiol. Zool. 55, 105-111. doi: 10.1086/physzool.55.1.30158447

Krebs, H. A. (1975). The August Krogh principle: "For many problems there is an animal on which it can be most conveniently studied". J. Exp. Zool. 194, 221-226. doi: 10.1002/jez.1401940115

Kvietys, P. R., and Granger, D. N. (1982). Relation between intestinal blood flow and oxygen uptake. Am. J. Physiol. 242, G202-G208. doi: 10.1152/ajpgi.1982.242.3.G202

Le Boeuf, B. J., Costa, D. P., Huntley, A. C., and Feldkamp, S. D. (1988). Continuous, deep diving in female Northern seals, Mirounga angustirostris. Can. J. Zool. 66, 446-458. doi: 10.1139/z88-064

Lenfant, C., Johansen, K., and Torrance, J. D. (1970). Gas transport and oxygen storage capacity in some pinnipeds and the sea otter. Respir. Physiol. 9, 277-286. doi: 10.1016/0034-5687(70)90076-9

Lenfant, C., Kooyman, G. L., Elsner, R., and Drabek, C. M. (1969). Respiratory function of blood of the adult and fetus Weddell seal (Leptonychotes weddelli). Am. J. Physiol. 216, 1595-1597. doi: 10.1152/ajplegacy.1969.216. 6.1595

Lutz, J., Henrich, H., and Bauereisen, E. (1975). Oxygen supply and uptake in the liver and the intestine. Pflugers Archiv. 360, 7-15. doi: 10.1007/BF00584322

McDonald, B. I., and Ponganis, P. J. (2012). Lung collapse in the diving sea lion: hold the nitrogen and save the oxygen. Biol. Lett. 8, 1047-1049. doi: 10.1098/rsbl.2012.0743

McDonald, B. I., and Ponganis, P. J. (2013). Insights from venous oxygen profiles: oxygen utilization and management in diving California sea lions. J. Exp. Biol. 216, 3332-3341. doi: 10.1242/jeb.085985

McDonald, B. I., and Ponganis, P. J. (2014). Deep-diving sea lions exhibit extreme bradycardia in long-duration dives. J. Exp. Biol. 217, 1525-1534. doi: $10.1242 / \mathrm{jeb} .098558$

McHuron, E. A., Block, B. A., and Costa, D. P. (2018). Movements and dive behavior of juvenile California sea lions from Año Nuevo Island. Mar. Mamm. Sci. 34, 238-249. doi: 10.1111/mms.12449

McHuron, E. A., Robinson, P. W., Simmons, S. E., Kuhn, C. E., Fowler, M., and Costa, D. P. (2016). Foraging strategies of a generalist marine predator inhabiting a dynamic environment. Oecologia 182, 995-1005. doi: $10.1007 / \mathrm{s} 00442-016-3732-0$
Meir, J. U., Champagne, C. D., Costa, D. P., Williams, C. L., and Ponganis, P. J. (2009). Extreme hypoxemic tolerance and blood oxygen depletion in diving elephant seals. Am. J. Physiol. Reg. Integr. Comp. Physiol. 297, R927-R939. doi: 10.1152/ajpregu.00247.2009

Meir, J. U., and Ponganis, P. J. (2009). High-affinity hemoglobin and blood oxygen saturation in diving emperor penguins. J. Exp. Biol. 212, 3330-3338. doi: $10.1242 /$ jeb. 033761

Meir, J. U., Stockard, T. K., Williams, C. L., Ponganis, K. V., and Ponganis, P. J. (2008). Heart rate regulation and extreme bradycardia in diving emperor penguins. J. Exp. Biol. 211, 1169-1179. doi: 10.1242/jeb.013235

Melin, S. R., DeLong, R. L., and Siniff, D. B. (2008). The effects of El Niño on the foraging behavior of lactating California sea lions (Zalophus californianus californianus) during the nonbreeding season. Can. J. Zool. 86, 192-206. doi: 10.1139/Z07-132

Milsom, W. K., Johansen, K., and Millard, R. W. (1973). Blood respiratory properties in some Antarctic birds. Condor 75, 472-474. doi: 10.2307/1366574

Mitz, S. A., Reuss, S., Folkow, L. P., Blix, A. S., Ramirez, J. M., Hankeln, T., et al. (2009). When the brain goes diving: glial oxidative metabolism may confer hypoxia tolerance to the seal brain. Neuroscience 163, 552-560. doi: $10.1016 /$ j.neuroscience.2009.06.058

Motterlini, R., and Otterbein, L. E. (2010). The therapeutic potential of carbon monoxide. Nat. Rev. Drug Discov. 9, 728-743. doi: 10.1038/nrd3228

Ponganis, P. J. (2015). Diving Physiology of Marine Mammals and Seabirds. Cornwall: Cambridge University Press.

Ponganis, P. J., Kreutzer, U., Stockard, T. K., Lin, P. C., Sailasuta, N., Tran, T.-K., et al. (2008). Blood flow and metabolic regulation in seal muscle during apnea. J. Exp. Biol. 211, 3323-3332. doi: 10.1242/jeb.018887

Powers, S. K., and Jackson, M. J. (2008). Exercise-induced oxidative stress: cellular mechanisms and impact on muscle force production. Physiol. Rev. 88, 1243-1276. doi: 10.1152/physrev.00031.2007

Pugh, L. G. C. E. (1959). Carbon monoxide content of the blood and other observations on Weddell seals. Nature 183, 74-76. doi: 10.1038/183074a0

Qvist, J., Weber, R. E., and Zapol, W. M. (1981). Oxygen equilibrium properties of blood and hemoglobin of fetal and adult Weddell seals. J. Appl. Physiol. 50, 999-1005. doi: 10.1152/jappl.1981.50.5.999

Ridgway, S., Houser, D., Finneran, J., Carder, D., Keogh, M., Van Bonn, W., et al. (2006). Functional imaging of dolphin brain metabolism and blood flow. J. Exp. Biol. 209, 2902-2910. doi: 10.1242/jeb.02348

Robinson, P. W., Costa, D. P., Crocker, D. E., Gallo-Reynoso, J. P., Champagne, C. D., Fowler, M. A., et al. (2012). Foraging behavior and success of a mesopelagic predator in the northeast Pacific Ocean: insights from a data-rich species, the northern elephant seal. PLoS ONE 7:e36728. doi: 10.1371/journal.pone.0036728

Sato, K., Naito, Y., Kato, A., Niizuma, Y., Watanuki, Y., Charassin, J. B., et al. (2002). Buoyancy and maximal diving depth in penguins: do they control inhaling air volume? J. Exp. Biol. 205, 1189-1197.

Sato, K., Shiomi, K., Marshall, G., Kooyman, G. L., and Ponganis, P. J. (2011). Stroke rates and diving air volumes of emperor penguins: implications for dive performance. J. Exp. Biol. 214, 2854-2863. doi: 10.1242/jeb.055723

Schneuer, M., Flachsbarth, S., Czech-Damal, N. U., Folkow, L. P., Siebert, U., and Burmester, T. (2012). Neuroglobin of seals and whales: Evidence for a divergent role in the diving brain. Neuroscience 223, 35-44. doi: 10.1016/j.neuroscience.2012.07.052

Shang, Y., Ting, L., and Yu, G. (2017). Clinical applications of near-infrared diffuse correlation spectroscopy and tomography for tissue blood flow monitoring and imaging. Physiol. Meas. 38, R1-R26. doi: 10.1088/1361-6579/aa60b7

Smith, Z. M., Krizay, E., Guo, J., Shin, D. D., Scadeng, M., and Dubowitz, D. J. (2013). Sustained high-altitude hypoxia increases cerebral oxygen metabolism. J. Appl. Physiol. 114, 11-18. doi: 10.1152/japplphysiol.00703.2012

Stockard, T. K., Levenson, D. H., Berg, L., Fransioli, J. R., Baranov, E. A., and Ponganis, P. J. (2007). Blood oxygen depletion during rest-associated apneas of northern elephant seals (Mirounga angustirostris). J. Exp. Biol. 210, 2607-2617. doi: $10.1242 /$ jeb. 008078

Storz, J. F. (2016). Hemoglobin-oxygen affinity in high-altitude vertebrates: is there evidence for an adaptive trend? J. Exp. Biol. 219, 3190-3203. doi: $10.1242 /$ jeb. 127134

Storz, J. F., Runck, A. M., Moriyama, H., Weber, R. E., and Fago, A. (2010). Genetic differences in hemoglobin function between highland and lowland deer mice. J. Exp. Biol. 213, 2565-2574. doi: 10.1242/jeb.042598 
Tift, M. S., Hückstädt, L. A., McDonald, B. I., Thorson, P. H., and Ponganis, P. J. (2017). Flipper stroke rate and venous oxygen levels in freeranging California sea lions. J. Exp. Biol. 220, 1533-1540. doi: 10.1242/jeb. 152314

Tift, M. S., Hückstädt, L. A., and Ponganis, P. J. (2018). Anterior vena caval oxygen profiles in a deep-diving California sea lion: arteriovenous shunts, a central venous oxygen store and oxygenation during lung collapse. J. Exp. Biol. 221:jeb163428. doi: 10.1242/jeb.163428

Tift, M. S., Ponganis, P. J., and Crocker, D. E. (2014). Elevated carboxyhemoglobin in a marine mammal, the northern elephant seal. J. Exp. Biol. 217, 1752-1757. doi: $10.1242 /$ jeb. 100677

Tift, M. S., Ranalli, E. C., Houser, D. S., Ortiz, R. M., and Crocker, D. E. (2013). Development enhances hypometabolism in northern elephant seal pups (Mirounga angustirostris). Funct. Ecol. 27, 1155-1165. doi: 10.1111/1365-2435. 12111

Valtin, H. (1973). Renal Function: Mechanisms Preserving Fluid and Solute Balance in Health. Boston, MA: Little, Brown \& Co.

Vázquez-Medina, J. P., Zenteno-Savín, T., and Elsner, R. (2007). Glutathione protection against dive-associated ischemia/reperfusion in ringed seal tissues. J. Exp. Mar. Biol. Ecol. 345, 110-118. doi: 10.1016/j.jembe.2007.02.003

Vazquez-Medina, J. P., Zenteno-Savin, T., Forman, H. J., Crocker, D. E., and Ortiz, R. M. (2011a). Prolonged fasting increases glutathione biosynthesis in postweaned northern elephant seals. J. Exp. Biol. 214, 1294-1299. doi: $10.1242 /$ jeb. 054320

Vazquez-Medina, J. P., Zenteno-Savin, T., Tift, M. S., Forman, H. J., Crocker, D. E., and Ortiz, R. M. (2011b). Apnea stimulates the adaptive response to oxidative stress in elephant seal pups. J. Exp. Biol. 214, 4193-4200. doi: $10.1242 /$ jeb.063644
Vedvick, T. S., and Itano, H. A. (1976). Partial characterization of the hemoglobin from Hubbs' beaked whale (Mesoplodon carlhubbsi). Comp. Biochem. Physiol. 55B, 65-68. doi: 10.1016/0305-0491(76)90174-7

Watanabe, S., Sato, K., and Ponganis, P. J. (2012). Activity time budget during foraging trips of emperor penguins. PLoS ONE 7:e50357. doi: 10.1371/journal.pone.0050357

Weber, R. E. (2007). High-altitude adaptations in vertebrate hemoglobins. Respir. Physiol. Neurobiol. 158, 132. doi: 10.1016/j.resp.2007.05.001

Weber, R. E., Jarvis, J. U. M., Fago, A., and Bennett, N. C. (2017). $\mathrm{O}_{2}$ binding and $\mathrm{CO}_{2}$ sensitivity in haemoglobins of subterranean African mole rats. J. Exp. Biol. 220, 3939-3948. doi: 10.1242/jeb.160457

White, J. R., Harkness, D. R., Isaacks, R. E., and Duffield, D. A. (1976). Some studies on blood of the Florida manatee, Trichechus manutus latirostris. Comp. Biochem. Physiol. A 55, 413-417. doi: 10.1016/0300-9629(76)90070-0

Wright, A. K., Ponganis, K. V., McDonald, B. I., and Ponganis, P. J. (2014). Heart rates of emperor penguins diving at sea: implications for oxygen store management. Mar. Ecol. Prog. Ser. 496, 85-98. doi: 10.3354/meps10592

Conflict of Interest Statement: The authors declare that the research was conducted in the absence of any commercial or financial relationships that could be construed as a potential conflict of interest.

Copyright (ㄷ) 2019 Tift and Ponganis. This is an open-access article distributed under the terms of the Creative Commons Attribution License (CC BY). The use, distribution or reproduction in other forums is permitted, provided the original author(s) and the copyright owner(s) are credited and that the original publication in this journal is cited, in accordance with accepted academic practice. No use, distribution or reproduction is permitted which does not comply with these terms. 